\title{
PENGARUH PERSONAL SELLING, DISPLAY PRODUCT DAN STORE ATMOSPHERE TERHADAP IMPULSE BUYING
}

\author{
Didid Haris Bahtiyar Rizal \\ Department of Management FEB UMM \\ E-mail:didid_hbr@yahoo.co.id
}

\begin{abstract}
This research aims to examine and analyze the effects of personal selling, product display, and store atmosphere simultaneously and partially towards consumer impulse buying consumer hypermart departemen store Malang Town Square. The sample size consisted of 100 respondents taken by accidental sampling. The data was analyzed by using the multiple linear regressions. The results showed personal selling, product display, and store atmosphere has the effect of simultaneously and partially towards impulse buying department store consumer matahari departemen store Malang Town Square. Variables store atmosphere dominant influence impulse buying in the consumer hypermart departemen store Malang Town Square.
\end{abstract}

Keywords:personal selling, display product, store atmosphere, impulse buying.

\section{PENDAHULUAN}

Pembelian impulsive adalah perilaku berbelanja yang terjadi secara tidak terencana, tertarik secara emosional, dimana proses pembuatan keputusan dilakukan dengan cepat tanpa berpikir secara bijak dan pertimbangan terhadap keseluruhan informasi dan alternatif yang ada (Rook dalam Bayley dan Nancarrow, 1998). Studi yang dilakukan Bellenger dalam Mattila dan Wirtz (2008) menyebutkan bahwa jumlah pembelian impulsif yang terjadi di department store di Amerika Serikat mencapai 27 sampai 62 persen dari seluruh pembelian. Data ini juga didukung oleh hasil studi yang dilakukan Nichols dalam Coley dan Burgess (2003) yang menyebutkan 50 persen pembeli di mall berbelanja secara impulsif. Perilaku belanja impulsif juga terjadi di Indonesia, terlihat dari hasil survei yang dilakukan oleh Nielsen dalam Divianto (2013) menyatakan bahwa 85 persen konsumen ritel moderen di Indonesia cenderung untuk berbelanja secara impulsif. Mengingat bahwa besarnya pengaruh pembelian impulsive terhadap total penjualan, maka pemasar itu perlu untuk mengidentifikasi faktor-faktor penyebabnya untuk dapat memformulasikan strategi pemasaran yang tepat (Hausman, 2000). Bisnis yang berkembang pesat di Indonesia saat ini salah satunya adalah bisnis retail. Pertumbuhan bisnis retail dipicu atas perkembangan ekonomi Indonesia yang cukup bagus, serta bertambahnya jumlah penduduk kelas menengah yang akan menjadi 
katalis peningkatan bisnis ritel tahun ini. Ritel di Indonesia pada masa sekarang ini, telah berkembang dari gerai tradisional seperti pasar atau warung maupun toko menjadi gerai yang lebih modern seperti supermarket. Konsep yang kemudian muncul dan berkembang dalam industri ritel adalah konsep one stop shopping, yang merupakan suatu tempat berbelanja yang memenuhi semua kebutuhan konsumen (Ma'ruf, 2006).

Salah satu bentuk perilaku konsumen yang tidak punya rencana adalah terjadinya impulse buying (membeli tanpa rencana/spontan membeli ketika tertarik dengan sebuah produk). Tidak mengherankan, tingkat pembelian secara tidak terencana di Indonesia relatif lebih tinggi dibandingkan dengan konsumen di Amerika Serikat.

Pembelian tidak terencana biasanya konsumen merasakan ketertarikan secara emosional saat mereka melihat produk-produk yang ditawarkan dan seringkali tidak lagi melibatkan rasionalitas dalam menentukan keputusan pembelian. Ketertarikan emosional itu muncul biasanya karena ada beberapa faktor simultan yang diterima oleh konsumen, diantaranya yaitu adanya tawaran dari para penjaga toko yang menawarkan sesuatu kepada mereka. Para konsumen bisanya cenderung membutuhkan opini atau persetujuan dari orang disekitarnya dalam penentuan keputusan membeli bisa dari pasangan, keluarga, teman dekat, dan tak luput pula, pendapat dari sales person (SPG) yang berada di toko, tempat mereka akan membeli produk.
Kepercayaan konsumen pada opini wiraniaga (pelayan toko) harus dipertimbangkan dalam mengembangkan strategi promosi (Engel et al, 2008). Ketika konsumen dalam kondisi "terdesak" merasa harus membeli dan memiliki barang/produk segera saat itu juga. Perilaku pelayan toko dapat mempengaruhi segala kemungkinan yang terjadi di titik beli. Mereka dapat mengubah keragu-raguan antara membeli atau tidak membeli (Peter dan Olson, 2008). Bahkan menurut Engel et al (2008), potensi untuk mempengaruhi konsumen selama berbelanja dapat dipengaruhi secara kuat oleh staf garis depan. Minat konsumen untuk melakukan pembelian jugadipengaruhi oleh suasana tempat perbelanjaan yang menyenangkan bagi konsumen. Perasaan senang atau positif emosional tersebut akan sangat berpengaruh terhadap ketertarikan mengunjungi sebuah tempat. Peter dan Olson (2008) menyatakan bahwa tiga keputusan utama dalam mendesain lingkungan fisik suatu usaha adalah lokasi, tata letak, serta rangsangan atau atmosphere yang ditimbulkannya.

Konsumen akan merasakan bagi mereka suasana belanja yang nyaman, aman dan menyenangkan akan menjadi faktor pertimbangan penting bagi mereka saat mereka akan mengunjungi sebuah tempat. Chen dan Hsieh (2010) mengatakan identitas sebuah toko dapat dikomunikasikan terhadap konsumen melalui dekorasi toko atau secara lebih luas dari atmosfernya. Meskipun store atmosphere tidak secara langsung mengkomunikasikan kualitas produk dibandingkan dengan 
melalui iklan, store atmosphere merupakan komunikasi secara diamdiam yang dapat menunjukkan kelas sosial dari produk-produk yang ada di dalammya. Sehingga hal ini dapat dijadikan sebagai alat untuk membujuk konsumen membeli produk yang dijual di toko tersebut.

Hypermart Departemen Store Malang Town Square merupakan salah satu tempat perbelanjaan bergerak di bidang retail yang menyediakan pakaian, aksesoris, perlengkapan kecantikan, dan perlengkapan rumah untuk konsumen yang menghargai mode dan nilai tambah. Didukung oleh jaringan pemasok lokal dan internasional terpercaya, gabungan antara mode yang terjangkau, gerai dengan visual menarik, berkualitas dan modern, memberikan pengalaman berbelanja yang dinamis dan menyenangkan, dan menjadikan Hypermart Departemen Store Malang Town Square sebagai pilihan utama bagi kelas menengah Indonesia yang tengah tumbuh pesat. Perusahaan ini tentunya sangat mengedepankan kualitas pelayanannya bagi konsumen dari semua segi baik dari kecakapan para staf personal selling-nya, dari tata letak atau display produk-produk yang ditawarkan serta kenyamanan para konsumennya saat berbelanja.

Dengan demikian perumusan masalah dalam penelitian sebagai berikut : 1. Bagaimana pengaruh personal selling, display product, dan store atmosphere terhadap impulse buying?. 2. Apakah personal selling, display product, dan store atmosphere berpengaruh secara simultan terhadap impulse buying?. 3. Apakah personal selling, display product, dan store atmosphere berpengaruh secara parsial terhadap impulse buying?. 4. Manakah diantara personal selling, display product, dan store atmosphere yang dominan pengaruhnya terhadap terhadap impulse buying .

Tujuan penelitian ini adalahsebagai berikut:1. Untuk mengetahui pengaruh personal selling, display product, dan store atmosphere terhadap impulse buying. 2. Untuk menguji dan menganalisis pengaruh personal selling, display product, dan store atmosphere secara simultan terhadap impulse buying. 3 . Untuk menguji dan menganalisis pengaruh personal selling, display product, dan store atmosphere secara parsial terhadap impulse buying. 4. Untuk menguji dan menganalisis pengaruh personal selling, display product, dan store atmosphere yang dominan pengaruhnya terhadap impulse buying.

\section{TINJAUAN PUSTAKA}

Penelitian yang dilakukan oleh Nilam dan Nuzulia (2014) menyimpulkan efektivitas personal selling dan sales promotion berpengaruh terhada impulse buying. Penelitian yang dilakukan oleh Divianto (2013) menyimpulkan bahwa variabel promosi penjualan, display toko dan personal selling secara simultan berpengaruh terhadap keputusan impulse buying, sedangkan penelitian yang dilakukan oleh Rahmasari (2010) menyimpulkan bahwa store environment, positive emotions, personal selling, dan in store promotion secara bersama sama memberikan pengaruh yang signifikan terhadap impulse buying. 
Personal selling merupakan salah satu komponen promotion mix di samping advertising, sales promotion dan publicity yang menekankan pada komunikasi yang bersifat persuatif untuk dapat

menggugah kemungkinan konsumen untuk melakukan pembelian. Personal selling adalah presentasi pribadi oleh para wiraniaga (tenaga penjual) perusahaan dalam rangka mensukseskan penjualan dan membangun hubungan dengan pelanggan (Kotler, 2012).

Menurut Kotler dan Keller (2009) personal selling memiliki beberapa teknik yaitu:Mencari calon pelanggan, Pendekatan, Presetasi dan demonstrasi, Mengatasi keberatan, Penutupan, dan Tindak lanjut dan pemeliharaan.

Display merupakan usaha mendorong perhatian dan minat konsumen pada toko atau barang dan mendorong keinginan membeli melalui daya tarik secara langsung (direct visual appea) (Alma, 2004).

Display dapat dibagi ke dalam beberapa jenis, yaitu: 1 . Window Display, yaitu memajang barang-barang, gambar-gambar, kartu harga, simbol-simbol dan sebagainya di bagian depan toko yang disebut etalase. 2. Interior Display, yaitu memajang barangbarang, gambar-gambar, kartu harga, poster-poster didalam toko, misalnya dilantai, di meja, di rak-rak dan sebagainya. 3. Exterior Display, yaitu memajangkan barang-barang diluar toko, misalnya pada waktu mengadakan obral atau pasar malam (Alma 2004).

Store atmosphere merupakan unsur senjata lain yang dimiliki toko. Setiap toko mempunyai tata letak fisik yang memudahkan atau menyulitkan pembeli untuk berputarputar didalamnya. Setiap toko mempunyai penampilan. Toko harus membentuk suasana terencana yang sesuai dengan pasar sasarannya dan yang dapat menarik konsumen untuk membeli (Kotler dan Keller, 2009).

Store atmospheremenurut Berman dan Evans dalam Fuad (2010)terdiri dan empat elemen yang berpengaruh terhadap suasana toko yang ingin diciptakan, yaitu : Pertama, Store exterior (bagian depan toko), mencerminkan kemantapan dan kekokohan spirit perusahaan dan sifat kegiatan yang ada di dalamnya, serta dapat menciptakan kepercayaan dan goodwill bagi konsumen Store exterior berfungsi sebagai identifikasi atau tanda pengenalan, sehingga sering menyatakan lambang. Yang termasuk bagian dari store exterior adalah bangunan luar, papan nama toko, pintu masuk, tinggi dan luas bangunan, keunikan, fasilitas parkir, lingkungan sekitar, dan keamanan kendaraan.

Kedua, General interior (interior umum)dari suatu toko harus dirancang untuk memaksimalkan visual merchandising. Seperti yang kita ketahui hal ini akan dapat menarik pembeli untuk datang ke toko, tapi yang paling utama yang dapat membuat penjualan setelah pembelian berada di toko adalah display. Kesan general interior ini dapat diciptakan melalui tata letak toko, pewarnaan dan pencahayaan, aroma dan suara, perabot toko, suhu udara, pengaturan rak barang yang rapi, pegawai yang ramah, kebersihan toko, barang dagangan, kasir, serta kebersihan. Ketiga, Store 
layout (tata letak) toko merupakan rencana untuk menentukan lokasi tertentu dan pengaturan dari jalan/gang di dalam toko yang cukup lebar yang memudahkan para konsumen untuk berlalu-lalang di dalamnya. Store layout akan mengundang masuk atau menyebabkan konsumen menjauhi toko tersebut ketika konsumen melihat bagian dalam toko melalui jendela etalase atau pintu masuk. Layout yang baik akan mampu mengundang konsumen untuk betah berkeliling lebih lama dan membelanjakan uangnya lebih banyak. Yang termasuk store layout adalah alokasi lantai ruangan, jenis barang, penataan barang, fasilitas toko, pengaturan toko serta kelompok barang. Keempat, Interior Displaymerupakan tanda-tanda yang digunakan untuk memberikan informasi kepada konsumen untuk mempengaruhi suasana lingkungan toko, dengan tujuan utama untuk meningkatkan penjualan dan laba toko tersebut. Yang termasuk interior display ialah poster, tanda petunjuk lokasi, tanda gambar special event seperti lebaran dan tahun baru, media pembungkus, dan rack and cases display.

Pembelian tidak terencana adalah tindakan membeli yang sebelumnya tidak diakui secara sadar sebagai hasil dari pertimbangan, atau niat membeli yang terbentuk sebelum memasuki toko. Atau bisa juga dikatakan suatu desakan hati yang tiba-tiba dengan penuh kekuatan, bertahan dan tidak direncanakan untuk membeli sesuatu secara langsung, tanpa banyak memperhatikan akibatnya (Mowen dan Minor, 2002).
Terdapat empat tipe pembelian tidak terencana (impulse buying), yaitu: 1. Impuls murni (pure impulse), pengertian ini mengacu pada tindakan pembelian sesuatu karena alasan menarik, biasanya ketika pembelian terjadi karena loyalitas terhadap merek atau perilaku pembelian yang telah biasa dilakukan. 2. Impuls pengingat (reminder impulse impulse), tindakan pembelian ini dikarenakan suatu produk biasanya memang dibeli oleh konsumen, tetapi tidak tercatat dalam daftar belanja. 3. Impuls saran (suggestion impulse), suatu produk yang dilihat konsumen untuk pertama kali akan menstimulasi keinginan konsumen untuk mencobanya. 4. Impuls terencana (planned impulse), aspek perencanaan dalam perilaku ini menunjukkan respon konsumen terhadap beberapa insentif spesial untuk membeli produk yang diantisipasi. Impuls ini biasanya distimulasi oleh pengumuman penjualan kupon, potongan kupon, atau penawaran menarik lainnya(Utami, 2010).

Personal selling merupakan salah satu kunci yang memegang peran penting dalam mengkomunikasikan citra merk dan image toko ke konsumen, sehingga dianggap salah satu kekuatan untuk mencapai keunggulan kompetitif di ritel industri (Hendrick dalam Nurmasarie dan Iriani, 2013).

Apalagi ketika perilaku impuls dan sales person dapat mengubah keragu-raguan konsumen antara membeli atau tidak (Peter dan Olson, 2008). Hal ini sesuai dengan penelitian Tendai dan Crispen (2009), dan Hadjali et al (2012) 
menunjukkan bahwa variabel personal selling berpengaruh secara signifikan

terhadap impulse buying.Display adalah keinginan membeli sesuatu, yang tidak didorong oleh seseorang,tapi didorong oleh daya tarik, atauoleh penglihatan ataupun olehperasaan lainnya (Alma, 2004).

Konsumen dengan kelas menengah ke atas cenderung memerlukan pencarian informasi yang lebih banyak sebelum pembelian di lakukan, sebaliknya konsumen dari kelompok menengah ke bawah lebih suka mendasarkan keputusan pembeliannya berdasarkan display di toko atau percaya pada petugas penjualan (Sutisna, 2001).

Apabila konsumen tertarik dan puas terhadap barang tersebut maka dapat memberikan manfaat diantaranya hubungan antara perusahaan dan konsumen menjadi harmonis, hal ini akan menjadi dasar yang baik untuk melakukan pembelian ulang. Konsumen, serta membentuk suatu rekomendasi dari mulut ke mulut yang dapat menguntungkan perusahaan sehingga dapat terlihat bahwa hubungan display dengan impulse buying erat kaitannya, karena tanpa adanya display, maka salah satu faktor yang dapat meningkatkan impulse buying tidak akan terpenuhi. Hal ini sesuai dengan penelitian Divianto (2013) dan Sipahutar (2013) yang menyatakan bahwa display berpengaruh secara signifikan terhadap impulse buying

Store atmosphere mempengaruhi keadaan emosi seorang konsumen yang akan menyebabkan meningkatnya atau menurunnya pembelian. Keadaan emosional akan membuat dua perasaan yang dominan, yaitu perasaan senang dan membangkitkan keinginan, baik yang muncul dari psychological set ataupun keinginan yang bersifat mendadak (impulse) (Sutisna dalam Fuad, 2010).

Storeatmosphere

memperbesar kemungkinan terjadinya perilaku impulsif (Youn dan Faber, 2000). Park dan Lennon (2006) menyatakan pembeli impusif sangat menyukai stimulus store atmosphere untuk merangsang respon pembelian secara tiba-tiba. Penelitian Soars (2009) menemukan adanya pengaruh positif store atmosphere terhadap pembelian impulsif. Peritel sangat penting untuk mengetahui faktor-faktor yang dapat mempengaruhi pembelian impulsif yang terjadi di dalam toko misalnya atmosfer toko (Fam et al, 2011).

Berdasarkan tinjauan teori, maka dapat disusun kerangka pikir dalam penelitian ini seperti tersaji dalam gambar 1 berikut ini :

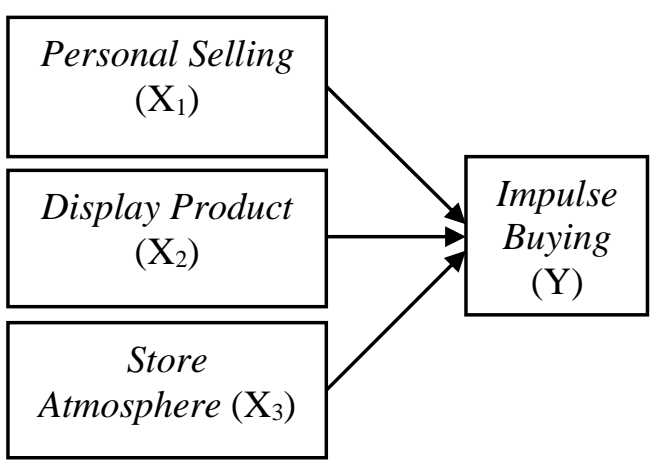

Gambar 1. Hubungan Personal Selling, Display Product, Store Atmosphere dengan Impulse Buying

Gambar di atas menunjukkan bahwa:1.Personal selling, display product, dan store atmosphere 
berpengaruh secara simultan terhadap impulse buying.2.Personal selling, display product, dan store atmosphere berpengaruh secara parsial terhadap impulse buying.3.Diduga bahwa variabel personal selling adalah yang dominan berpengaruh terhadap impulse buying.

\section{METODE PENELITIAN}

Lokasi penelitian ini dilakukan di Hypermart Departemen Store Malang Town Square Jl. Veteran No. 2 Malang. Lokasi ini dipilih guna mendapatkan responden yang sesuai dengan yang diinginkan oleh peneliti. Penelitian ini mencakup keseluruhan konsumen yang berbelanja di Hypermart Departemen Store Malang Town Square.

Jenis penelitian yang digunakan adalah survey yaitu mengambil sampel dari suatu populasi dengan menggunakan kuesioner sebagai alat pengumpulan data yang pokok.Populasi dalam penelitian ini adalah 100 orang. Teknik sampling yang digunakan dalam penelitian ini adalah accidental sampling, yaitu siapa saja yang secara kebetulan bertemu dengan peneliti dapat digunakan sebagai sampel bila orang yang ditemui cocok dan memenuhi kriteria sebagai sumber data.

Variabel penelitian adalah personal selling, display product, storeatmosphere, terhadap variabel impulse buying.Teknik pengumpulan data yang dilakukan adalah kuesioner. Setelah data terkumpul tahap selanjutnya adalah mengklarifikasi dan melakukan analisis data dengan menggunakan analisis regresi linier berganda, uji F, uji t, dan R Square.

Persamaan analisa regresi linier berganda dalam penelitian ini adalah sebagai berikut :

$$
\mathrm{Y}=\mathrm{b}_{0}+\mathrm{b}_{1} \mathrm{X}_{1}+\mathrm{b}_{2} \mathrm{X}_{2}++\mathrm{b}_{3} \mathrm{X}_{3}+\mathrm{e}
$$

$$
\begin{array}{cll}
\begin{array}{c}
\text { Keterangan: } \\
\mathrm{Y}
\end{array} & : \text { Impulse buying } \\
\mathrm{b}_{0} & : \text { Konstan } \\
\mathrm{b}_{1}, \mathrm{~b}_{2}, \mathrm{~b}_{3} & : \text { Koefisien regresi } \\
\mathrm{e} & : & \text { Standar error } \\
\mathrm{X}_{1} & : & \text { Personal selling } \\
\mathrm{X}_{2} & : & \text { Display product } \\
\mathrm{X}_{3} & : & \text { Store atmosphere }
\end{array}
$$

\section{HASIL PENELITIAN DAN PEMBAHASAN}

Berdasarkan hasil dari perhitungan personal selling, display product dan storeatmosphere terhadap impulse buyingadalah tersaji pada tabel 1 sebagai berikut:

Tabel 1. Hasil perhitungan variabel personal selling, display product dan storeatmosphere terhadap impulse buying

\begin{tabular}{lccc}
\hline \multicolumn{1}{c}{ Variabel } & $\Sigma$ & $\begin{array}{c}\text { Rata } \\
2\end{array}$ & Kriteria \\
\hline $\begin{array}{l}\text { Personal } \\
\text { selling }\end{array}$ & 100 & 3,28 & Cukup \\
$\begin{array}{l}\text { Display } \\
\text { product }\end{array}$ & 100 & 3,58 & Tinggi \\
$\begin{array}{l}\text { Store } \\
\text { atmosphere }\end{array}$ & 100 & 3,28 & Cukup \\
$\begin{array}{l}\text { Impulse } \\
\text { buying }\end{array}$ & 100 & 3,39 & Cukup \\
\hline
\end{tabular}

Berdasarkan tabel 1 di atas terlihat bahwa personal selling memperoleh nilai rata-rata 3,28 yang berarti bahwa variabel personal 
selling memiliki pengaruh yang cukup terhadap impulse buying di Hypermart DepartmenStore Malang Town Square.

Berdasarkan tabel 1 diatas juga terlihatbahwa variabledisplay product memperoleh nilai rata-rata 3,58 yang berarti bahwa variabel display product memiliki pengaruh yang tinggi terhadap impulse buying di Hypermart DepartmenStore Malang Town Square.

Berdasarkan tabel 1 diatas juga terlihat bahwa variabel store atmosphere memperoleh nilai ratarata 3,28 yang berarti bahwa variabel store atmosphere memiliki pengaruh yang cukup terhadap impulse buying di Hypermart DepartmenStore Malang Town Square.

Berdasarkan tabel 1 diatas juga terlihat bahwa variabel impulse buying memperoleh nilai rata-rata 3,39, hal ini membuktikan bahwa konsumen Hypermart DepartmenStore Malang Town Square tertarik secara emosional seringkali tidak lagi melibatkan rasionalitas dalam proses pengambilan keputusan pembelian dan dapat menyebabkan konsumen melakukan tindakan pembelian.

saat konsumen terdesak merasa harus membeli dan memiliki barang/produk segera saat itu juga, maka perilaku sales person dapat mempengaruhi segala kemungkinan yang terjadi di keputusan pembelian,

Berdasarkan hasil analisis regresi linear berganda,bahwa pengaruh personal selling, display product dan storeatmosphere terhadap impulse buyingadalah tersaji pada tabel 2 sebagai berikut:
Tabel 2. Hasil perhitungan analisis regresi linier berganda variabel personal selling, display product dan storeatmosphere terhadap impulse buying

\begin{tabular}{|c|c|c|c|}
\hline Variabel & $\begin{array}{l}\text { Koefisen } \\
\text { Regresi }\end{array}$ & $\begin{array}{l}\text { Standar } \\
\text { Error }\end{array}$ & $t_{\text {hitun }}$ \\
\hline $\begin{array}{l}\text { rssonal } \\
\text { lling }\end{array}$ & 0,169 & 0,069 & 2,429 \\
\hline $\begin{array}{l}\text { isplay } \\
\text { roduct }\end{array}$ & 0,204 & 0,086 & 2, \\
\hline $\begin{array}{l}\text { Store } \\
\text { atmosphere }\end{array}$ & 0,222 & 0,052 & 4,291 \\
\hline \multicolumn{3}{|l|}{ Constanta } & 2, \\
\hline \multicolumn{3}{|c|}{ Adjusted R Square } & $: 0$ \\
\hline \multicolumn{3}{|c|}{ Koefisien Korelasi (R) } & $: 0,667$ \\
\hline \multicolumn{3}{|c|}{ Hasil perhitungan } & analisi \\
\hline \multicolumn{4}{|c|}{$\begin{array}{l}\text { regresi linier berganda yang } \\
\text { dilakukan menunjukkan pengaruh }\end{array}$} \\
\hline $\begin{array}{l}\text { dilakukan } \\
\text { variabel }\end{array}$ & ide & & - \\
\hline
\end{tabular}
variabel dependent adalah cukup. Hal tersebut dapat dilihat pada nilai Adjusted $R$ Square yaitu sebesar 0,428 .

Dengan demikian berarti bahwa personal selling, display product dan storeatmosphere dipengaruhi oleh impulse buying sebesar $42,8 \%$, sedangkan sisanya $57,2 \%$ dipengaruh oleh variabel lain yang tidak diteliti dalam penelitian ini.

Berdasarkan analisis regresi linier berganda, maka diperoleh persamaan regresi sebagai berikut :

$Y=2,783+0,169 X_{1}+0,204 X_{2}+0,222 X$ ${ }_{3}+\mathrm{C}$

Dari hasil di atas di peroleh nilai konstanta sebesar 2,783, hasil ini menunjukkan bahwa jika variabel personal selling $\left(\mathrm{X}_{1}\right)$, display product $\left(\mathrm{X}_{2}\right)$, dan store atmosphere $\left(\mathrm{X}_{3}\right) \quad$ konstanta/tetap, maka konsumen akan melakukan impulse 
buying di Hypermart Departemen Store Malang Town Square.

Personal selling yang terdiri dari indikator bertatap muka, bersikap ramah dengan costumer, memberikan penjelasan tentang produk, menangani keberatan, dan menanyakan pesanan customermemberikan pengaruh koefisien regresi positif sebesar 0,169 terhadap impulse buying, display productyang terdiri dari indikator penampakan etalase yang menarik, memberikan hiasan di dalam serta luar toko, memberi tanda/logo tentang produk yang dijual, dan menempatkan produk di tempat yang mudah dilihatmemberikan pengaruh koefisien regresi positif sebesar 0,204 terhadap impulse buying, dan store atmosphereyang terdiri dari indikator papan nama yang unik, tempat parkir yang luas, pencahayaan yang terang, suhu udara ruangan, personal yang rapi serta ramah, kebersihan ruangan, dan pengelompokan barang sejenis memberikan pengaruh koefisien regresi positif sebesar 0,222 terhadap impulse buying.

Dengan pengujian uji $\mathrm{F}$ diperoleh nilai $F_{\text {hitung }}$ sebesar 25,665 sedangkan $F_{\text {tabel }}$ pada taraf nyata $5 \%$ menunjukkan nilai sebesar 2,70, karena $F_{\text {hitung }}>F_{\text {tabel }}$ maka hipotesis nol (H0) di tolak dan Hipotesa alternatif (H1) diterima. Hal ini menunjukkan bahwa ketiga variabel independent (personal selling, display product, dan store atmosphere) secara bersama-sama mempengaruhi impulse buying

Dengan menggunakan test dua arah, derajat bebas 50 dan taraf nyata $5 \%$, diperoleh nilai tabel sebesar
1,983. Untuk menilai apakah $\mathrm{H} 0$ yang diterima ditolak, ditentukan kriteria sebagai berikut: 1. Jika $t_{\text {hitung }}>\mathrm{t}_{\text {tabel, }}$ maka $\mathrm{H} 0$ ditolak atau $\mathrm{H} 1$ diterima. 2. Jika $t_{\text {hitung }} \leq t_{a b e l}$, maka $H 0$ diterima atau $\mathrm{H} 1$ ditolak.

Dilihat dari thitung sebesar 2,429 , karena nilai $t_{\text {hitung }}>t_{\text {tabel }}$, maka $\mathrm{H}_{0}$ ditolak dan $\mathrm{H}_{1}$ diterima. Dengan demikian dapat dikatakan bahwa variabel personal selling adalah berpengaruh signifikan pada taraf nyata $(\alpha)=0,05$ dengan tingkat kepercayaan $95 \%$, nilai display product $t_{\text {hitung sebesar } 2,359 \text {, karena }}$ nilai $t_{\text {hitung }}>\mathrm{t}_{\text {tabel}}$, maka $\mathrm{H}_{0}$ ditolak dan $\mathrm{H}_{1}$ diterima. Dengan demikian dapat dikatakan bahwa variabel display product adalah berpengaruh signifikan pada taraf nyata $(\alpha)=0,05$ dengan tingkat kepercayaan $95 \%$, dan nilai store atmosphere $\mathrm{t}_{\text {hitung }}$ sebesar 4,291, karena nilai $t_{\text {hitung }}>$

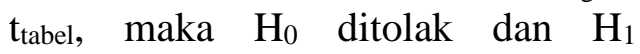
diterima. Dengan demikian dapat dikatakan bahwa variabel store atmosphere adalah berpengaruh signifikan pada taraf nyata $(\alpha)=0,05$ dengan tingkat kepercayaan $95 \%$.

Hasil yang diperoleh untuk hipotesis pertama penelitian ini menunjukkan bahwa personal selling berpengaruh positif terhadap impulse buying konsumen Hypermart Departemen Store Malang Town Square. Hal ini sejalan dengan teori yang dikemukakan oleh Peter dan Olson (2008) menyatakan bahwa perilaku impuls saat konsumen terdesak merasa harus membeli dan memiliki barang/produk segera saat itu juga, maka perilaku sales person dapat berpengaruh terhadap segala kemungkinan yang terjadi di keputusan pembelian, dan sales person dapat mengubah keragu- 
raguan konsumen antara membeli atau tidak. Pada saat yang bersamaan aspek personal selling ini juga merupakan salah satu sumber yang berpengaruh terhadap konsumen. Sedangkan menurut pendapat Park dan Lennon (2006) menyatakan bahwa pembelian secara impuls terjadi ketika kualitas, fungsi, dan kegunaan produk tersebut dieveluasi oleh pelanggan atau seorang personal selling.

Hal ini sesuai dengan penelitian Affandi (2011) yang menyebutkan bahwa faktor personal selling berpengaruh secara positif terhadap pembelian impuls. Juga dalam penelitian Tendai dan Crispen (2009), dan Hadjali et al (2012) menunjukkan bahwa variabel personal selling berpengaruh secara signifikan terhadap impulse buying. Oleh karena itu, personal selling seperti bertatap muka dengan costumer, bersikap ramah terhadap costumer, memberikan penjelasan tentang produk, dan menangani keberatan costumer yang diberikan oleh Hypermart Departemen Store Malang Town Square menjadi salah satu unsur dalam menentukan impulse buying.

Hasil yang diperoleh untuk hipotesis kedua penelitian ini menunjukkan bahwa display product berpengaruh positif terhadap impulse buying konsumen Hypermart Departemen Store Malang Town Square. Hal ini sejalan dengan teori yang dikemukakan oleh Sutisna (2001) yang menyatakan bahwa konsumen dengan kelas menengah ke atas cenderung memerlukan pencarian informasi yang lebih banyak sebelum pembelian di lakukan, sebaliknya konsumen dari kelompok menengah ke bawah lebih suka mendasarkan keputusan pembeliannya berdasarkan display di toko atau percaya pada petugas penjualan. Sedangkan menurut Alma (2004) menyatakan bahwa keinginan membeli sesuatu, yang tidak didorong oleh seseorang, tapi didorong oleh daya tarik, atau oleh penglihatan ataupun oleh perasaan lainnya.

Hasil penelitian ini sesuai dengan penelitian yang dilakukan oleh Divianto (2013) dan Sipahutar (2013) yang menyatakan bahwa display berpengaruh secara signifikan terhadap impulse buying. Sedangkan penelitian yang dilakukan oleh Haediwan (2013) menyatakan bahwa display berpengaruh signifikan terhadap intensi pembelian hal ini disebabkan oleh penampilkan etalase yang menarik, memberikan hiasan, memberikan logo tentang produk, dan penempatan barang yang mudah dilihat.

Hasil yang diperoleh untuk hipotesis ketiga penelitian ini menunjukkan bahwa store atmosphere berpengaruh positif terhadap impulse buying konsumen Hypermart Departemen Store Malang Town Square. Hal ini sejalan dengan teori yang dikemukakan oleh Sutisna dalam Fuad (2010) yang menyatakan bahwa store atmosphere berpengaruh terhadap keadaan emosi seorang konsumen yang akan menyebabkan meningkatnya atau menurunnya pembelian. Keadaan emosional akan membuat dua perasaan yang dominan, yaitu perasaan senang dan membangkitkan keinginan, baik yang muncul dari psychological set ataupun keinginan yang bersifat mendadak (impulse). 
Sedangkan menurut Park dan Lennon (2006) menyatakan pembeli impusif sangat menyukai stimulus store atmosphere untuk merangsang respon pembelian secara tiba-tiba.

Hasil penelitian ini sesuai dengan penelitian yang dilakukan oleh Soars (2009) dan Youn dan Faber (2000) yang menyimpulkan bahwa store atmosphere berpengaruh signifikan terhadap pembelian impulsif. Sedangkan penelitian yang dilakukan oleh Park dan Lennon (2006) menyatakan pembeli impusif sangat menyukai stimulus store atmosphere untuk merangsang respon

pembelian secara tibatiba.Berdasarkan ketiga variabel penelitian, yaitu personal selling, display product, dan store atmosphere terbukti berpengaruh positif dan signifikan baik secara simultan maupun parsial terhadap variabel impulse buying.

Variabel store atmosphere merupakan variabel yang yang paling berpengaruh terhadap impulse buying pada konsumen Hypermart Departemen Store Malang Town Square ditinjau dari papan nama yang unik, tempat parkir yang luas, pencahayaan yang terang, suhu udara ruangan, personal yang rapi serta ramah, kebersihan ruangan, dan pengelompokan barang sejenis.

\section{SIMPULAN}

dan pembahasan pada bab sebelumnya, maka dapat ditarik kesimpulan bahwa personal selling, display product, dan store atmosphere mempunyai pengaruh secara simultan terhadapimpulse buying pada konsumen Hypermart
Departemen Store Malang Town Square.

Personal selling, display product, dan store atmosphere mempunyai pengaruh secara parsial terhadap impulse buying pada konsumen Hypermart Departemen Store Malang Town Square.

Dari ketiga variabel personal selling, display product, dan store atmosphere, menunjukkan bahwa variabel store atmosphere merupakan variabel yang dominan berpengaruh terhadap impulse buying pada konsumen Hypermart Departemen Store Malang Town Square.Hal ini menunjukkan bahwa

Hypermart Departemen Store Malang Town Square memiliki peluang yang besar untuk dapat mempengaruhi konsumennya untuk melakukan impulse buying sehingga dapat menambah keuntungan perusahaan dan mampu memberikan kontribusi yang besar terhadap penciptaan impulse buying konsumen terhadap produk yang mereka tawarkan.

\section{DAFTAR PUSTAKA}

Affandi, S. 2011. Pengaruh Personal Selling dan Kesadaran Merek terhadap Keputusan Pembelian pada Produk You C1000 (Studi pada Carrefour $B G$ Junction Surabaya). Skripsi tidak diterbitkan. Surabaya: FE Unesa.

Alma, B. 2004. Manajemen Pemasaran dan Pemasaran Jasa. Bandung: Alfabeta.

Bayley, G., \& Nancarrow, C. 1998. Impulse purchasing: a qualitative exploration of the phenomenon, Qualitative 
Market Research: An International Journal, 1 (2): 99-114.

Chen, H., \& Hsieh, T. 2010. The effect of atmosphere on customer perceptions and customer behaviour responses in Chain Store Supermarkets. African Journal of Business Management, 5 (24): 1005410066.

Coley, A., \& Burgess, B. 2003. Gender differences in cognitive and affective impulse buying. Journal of Fashion Marketing and Management, 7 (3): 282-295.

Divianto. 2013. Pengaruh faktorfaktor in-store promotion terhadap impulse buying decision pada konsumen Hypermart PIM. Jurnal Ekonomi dan Informasi Akuntansi (Jenius), 3 (1): 94104.

Engel, J.F., Blackwell, R.D., \& Miniard, P.W. 2008. Perilaku Konsumen. Edisi Keenam. Jakarta: Binarupa Aksara.

Fam, K.S., Merrilees, B., Richard, J.E., Jozca, L., Li, Y., \& Krisjanous, J. 2011. In-store marketing: a strategic perspective. Asia Pasific Journal of Marketing and Logistics, 23 (2): 165-176.

Fuad, M. 2010. Store Atmosphere dan Perilaku Pembelian Konsumen di Toko Buku Gramedia Malang. Jurnal Manajemen Pemasaran Modern. 2 (1): 1-14.

Haediwan, M.E. 2013. Pengaruh Personal Selling dan Display Terhadap Intensi Pembelian
Produk di Distro Steady Store. Skripsi tidak dipublikasikan. Makassar: Universitas Hasanuddin.

Hadjali, H.Reza., Meysam, S., \& Masomeh, S.A. 2012. Exploring Main Factors Affecting on Impulse Buying Behaviours. Journal of American Science, 8 (1): 245251.

Hausman, A. 2000. A multi-method investigation of consumer motivations in impulse buying behavior. Journal of Consumer Marketing. 17 (5): 403-19.

Kotler, P, \& Armstrong, G. 2012.Principles ofMarketing. $14^{\text {th }} \quad$ Edition, Prentice Hall Pearson, USA.

Kotler, P., \& Keller, K.L. 2009. Manajemen Pemasaran. Edisi 13 Jilid 2. Alih Bahasa Bob Sabran. Jakarta: Erlangga.

Ma'ruf, H. 2006. Pemasaran Ritel. Jakarta: Gramedia Pustaka Utama.

Mattila, A.S., \& Wirtz, J. 2008. The role of store environmental stimulation and social factors on impulse purchasing. Journal of Services Marketing. 22 (7): 562-567.

Mowen, J.C., \& Minor, M. 2002. Perilaku Konsumen. Jakarta: Erlangga.

Nilam, N.D., \& Nuzulia, S. 2014. Efektivitas Personal Selling dan Sales Promotion dengan Sampel ProdukTerhadap Impulse Buying. Journal of Social and Industrial Psychology, 3(1): 41-47. 
Nurmasarie, R., \& Iriani, S.S. 2013. Pengaruh Promosi Penjualan dan Penjualan Perseorangan terhadap Keputusan Belanja Tidak Terencana. Jurnal Ilmu Manajemen, 1 (2): 528-540.

Park, Fihye dan Sharron F. Lennon. 2006. Psychological and environmental antecedents of impulse buying tendency in the multichannel shopping context. Journal of Consumer Marketing, 23(2): 58-68.

Peter, J.P., \& Jerry C.O. 2008. Consumer Bahaviour: Perilaku Konsumen dan Strategi Pemasaran. Jakarta: Erlangga.

Rahmasari, L. 2010. Menciptakan Impulse Buying. Majalah ilmiah informatika, 1 (3): 56-68.

Sipahutar, S. 2013. Pengaruh Display Toko dan Motivasi Belanja Berdasarkan Kesenangan (Hedonic) terhadap Pembelian Impulsif Pada Konsumen Ouval Research Bandung. Skripsi tidak dipublikasikan. Universitas Komputer Indonesia Bandung.

Soars, B. 2009. Driving sales through shopper's sense of sound, sight, smell, and touch. International Journal of Retail and Distribution Management, 37 (3): 286-298.

Sutisna. 2001. Perilaku Konsumen dan Komunikasi Pemasaran. Bandung: Remaja Rosdakarya.

Tendai, M., \& Crispen, C. 2009. Instore environment and impulsive buying. African Journal of Marketing Management, 1 (4): 102-108.

Utami, C.W. 2010. Manajemen Ritel: Strategi dan Implementasi Operasional Bisnis RitelModeren di Indonesia. Jakarta: Salemba Empat.

Youn, S., \& Faber, R.J. 2000. Impulse buying: its relation to personality traits and cues. Advances in Consumer Research, 27 (1): 179-185. 